\title{
Mapping Some Seed Quality Traits in Bread Wheat (Triticum aestivum L.) by Association Mapping Using SSR Markers
}

\author{
Reza Mir Drikvand ${ }^{1 *}$, Goodarz Najafiann ${ }^{2}$, Mohammad Reza Bihamta ${ }^{3}$, Asa Ebrahimi ${ }^{4}$ \\ 'Department of Agronomy and Plant Breeding, Khorramabad Branch, Islamic Azad University, Khorramabad, Iran \\ ${ }^{2}$ Cereal Chemistry and Technology Unit, Seed and Plant Improvement Institute, Karaj, Iran \\ ${ }^{3}$ Department of Agronomy and Plant Breeding, University of Tehran, Iran \\ ${ }^{4}$ Department of Plant Biotechnology, Science and Research Branch, Islamic Azad University, Tehran, Iran
}

Corresponding Author: Reza Mir Drikvand, Assistant Professor, Department of Agronomy and Plant Breeding, Khorramabad Branch, Islamic Azad University, Khorramabad, Iran. Tel: +98-6633120025, Fax: +98-6633120026, Email: drikvand_r@yahoo.com

Received June 14, 2018; Accepted August 23, 2018; Online Published September 30, 2018

\begin{abstract}
Introduction: Quality characteristics including grain protein content, gluten, falling number, and SDS sedimentation volume are important contributors to the grain yield and quality of the wheat. To identify the markers associated with such traits, this study run in two separated experiments: under-field and in laboratory.

Materials and Methods: One hundred wheat genotypes were evaluated in an alpha lattice design with two replications. Association mapping using Structure and Tassel software was carried out using 102 SSR markers: 66 unlinked and 36 quantitative trait loci (QTL)-linked SSR markers. Correction for population structure was performed using genome-wide SSR markers so that genotypes were divided into six subpopulations.

Results: Thoroughly, 34 SSR markers linked with the above-mentioned traits were identified, twelve of them being QTL-linked markers. These markers were already mapped on the wheat chromosomes in previous studies containing known QTLs controlling kernel traits of the wheat. Our results confirmed 5, 3, 2, and 2 QTLs respectively for the grain protein, gluten, falling number, and SDS sedimentation volume which were previously tagged on the wheat chromosomes. Additionally, $3 \mathrm{QTLs}$ were identified for the grain protein on the chromosomes $2 \mathrm{~A}$, $5 \mathrm{~A}, 5 \mathrm{D}$, and 7B. Whereas, 6 QTLs for gluten were detected on chromosomes $1 A, 2 D, 5 A, 5 B, 6 B$, and 7B; four QTLs were located on the chromosomes 2D, $5 A, 5 B, 5 D$, and $7 D$ for falling number; and finally nine QTLs were found for SDS sedimentation volume on the chromosomes $1 A, 1 B, 2 B, 3 A, 3 B$, $4 \mathrm{~B}, 6 \mathrm{~A}, 6 \mathrm{~B}, 7 \mathrm{~A}$, and $7 \mathrm{~B}$.

Conclusions: The results of this study indicated that association mapping is a useful method for detecting and complementing QTL information; thus, this information can be used for further wheat improvement based on a molecular marker.

Keywords: Association Mapping, Quality Traits, QTL, Wheat

Citation: Mir Drikvand R, Najafian G, Bihamta MR, Ebrahimi A. Mapping some seed quality traits in bread wheat (Triticum aestivum L.) by association mapping using SSR markers. J Appl Biotechnol Rep. 2018;5(3):92-99. doi:10.29252/jabr.05.03.02.
\end{abstract}

\section{Introduction}

Improvement of the end-use quality is one of the primary objectives of breeding for researchers working on raising the nutritional and functional quality of wheat. The processing and end-use characteristics of the grain, collectively known as quality traits, are under genetic and environmental control. Molecular genetic studies explaining this control may increase the efficiency of wheat breeding to improve the grain quality. Association mapping which is also referred to as linkage disequilibrium (LD) mapping has gained considerable popularity as an efficient genetic mapping methodology because of improved statistical approaches that increase its proficiency and reduce false positive associations. ${ }^{1}$ Furthermore, association mapping has been used to identify trait-marker relationships in plants. ${ }^{2,3}$ Initially, this method was extensively used to dissect human diseases. ${ }^{4}$ Unlike linkage analysis where mapping populations are used to determine correlations between phenotype and genotype, association mapping relies on unrelated individuals to create population-wide marker-phenotype associations. ${ }^{5}$ Linkage mapping based on the biparental populations is frequently used to dissect the genetic architecture of wheat quality traits. Several main effect QTLs and major genes have been identified for glutenin and grain hardness locus $\mathrm{Ha},{ }^{6}$ test weight, ${ }^{7-11} a$-amylase activity, ${ }^{10,12}$ grain protein content, ${ }^{11,13-19}$ sedimentation volume, ${ }^{10,20-22}$ and grain weight. ${ }^{23}$ The main objective of the association mapping studies is detecting the correlations between genotypes and phenotypes in a sample of individuals based on the $\mathrm{LD},{ }^{24}$ and it is suggested as a promising alternative strategy to linkage mapping. ${ }^{25}$ There are some examples of applying association mapping via wide genome or candidate genes approaches in wheat. Breseghello and Sorrells ${ }^{26}$ used association mapping and detected the main effect QTLs for the kernel weight, length, and width.

Copyright (C) 2018 The Author(s). This is an open-access article distributed under the terms of the Creative Commons Attribution License (http:// creativecommons.org/licenses/by/4.0), which permits unrestricted use, distribution, and reproduction in any medium, provided the original work is properly cited. 
Neumann et al used 96 bread wheat accessions and detected the main effect QTLs for several agronomic and quality traits such as protein content, sedimentation volume, and 1000-kernel weight. ${ }^{27}$ Jochen et al investigated the genetic basis of protein content, sedimentation volume, 1000-kernel weight, test weight, and starch content using an association mapping approach and detected the main effect QTLs for these traits. ${ }^{28}$

In contrast, it was found that the test weight and sedimentation volume were only controlled by epistatic QTLs. Emebiri et a $\mathrm{al}^{12}$ used a whole genome scan with DArT markers to identify chromosomal regions influencing late maturity a-amylase (LMA) in synthetic hexaploid wheat. They found significant markers at the chromosome 7B, a region previously linked to LMA in bread wheat, but not at the chromosome $3 \mathrm{~B}$ region, they concluded that a region on chromosome $6 \mathrm{~B}$ has potentially great interest for this trait and have a significant association with LMA phenotypes in the wheat accessions. Abdollahi Mandoulakani et a ${ }^{29}$ investigated associations between the ISSR, IRAP, REMAP markers and the agronomic traits of wheat. They found that 94 loci were significantly associated with agronomic traits. Shahzad et al experimented the grain quality traits, genetic diversity, and marker-trait association in a range of wheat species. ${ }^{30}$ In their study, 8 QTLs were found for 5 traits including protein, gluten contents, a test weight of bread, and chapati making quality. Protein content, test weight, bread quality, and Glu-B1 were found significantly associated respectively with primers WMC419 (32 cM), WMC128 (30 cM), WMC419 (32 cM), WMC818 (17 cM), and WMC416 (44 cM). Kumari et al also identified quantitative trait loci (QTL) regulating grain traits in wheat. ${ }^{31}$ They found 18 QTLs distributed on 8 chromosomes for 7 grain traits of bread wheat. Karolina et al confirmed the predominant effect of the Glu-D1d allele on the technological properties of wheat grains. ${ }^{32}$ In a study conducted by Kaur et al it was indicated that micro-sedimentation test values are not much affected by the absence of Glu-B3/Gli-B1, and hence, the lines having better root traits with no Glu-B3/ Gli-B1 and secalin could be used for improving the bread quality and yield in wheat. ${ }^{33}$ Our study aimed to evaluate the population structure of 92 bread wheat accessions using the association mapping method to detect SSR markers linked to the loci involved in quality characteristics of the bread wheat.

\section{Materials and Methods}

Plant Material and Field Experiment

A collection of 92 genotypes of bread wheat (Triticum aestivum) and 8 durum wheat (T. durum) (only used in field experiment) were used in this study (Table 1). These genotypes were cultivated in different regions of Iran and widely used in wheat production as well. This population consisted of local and modern cultivars as well as promising lines. The experiment was alpha lattice designed with 2 replications for 100 entries. The 92 bread wheat genotypes used for association mapping were evaluated according to AACC approval methods $39-25,38-12,56-81$, and $56-60^{34}$ for grain protein, gluten, falling number, and SDS sedimentation
Table 1. Information on Wheat Genotypes Used in This Study

\begin{tabular}{|c|c|c|}
\hline No. & Name/Identity & Growth Habit \\
\hline 1 & Karaj-1 & $\mathrm{F}$ \\
\hline 2 & Karaj-2 & $\mathrm{F}$ \\
\hline 3 & Karaj-3 & W \\
\hline 4 & Azadi & $\mathrm{S}$ \\
\hline 5 & Ghods & $\mathrm{S}$ \\
\hline 6 & Mahdavi & $\mathrm{F}$ \\
\hline 7 & Niknejad & $\mathrm{S}$ \\
\hline 8 & Marvdasht & $\mathrm{S}$ \\
\hline 9 & Pishtaz & $\mathrm{S}$ \\
\hline 10 & Shiraz & $\mathrm{S}$ \\
\hline 11 & Sepahan & $\mathrm{S}$ \\
\hline 12 & Bahar & $\mathrm{S}$ \\
\hline 13 & Parsi & $\mathrm{S}$ \\
\hline 14 & Sivand & $\mathrm{S}$ \\
\hline 15 & M-85-7 & $\mathrm{S}$ \\
\hline 16 & WS-82-9 & $\mathrm{S}$ \\
\hline 17 & Sirvan & $\mathrm{S}$ \\
\hline 18 & DN-11 & $\mathrm{S}$ \\
\hline 19 & Bezostaya & W \\
\hline 20 & Navid & F/W \\
\hline 21 & Alamout & F/W \\
\hline 22 & Alvand & $\mathrm{F}$ \\
\hline 23 & Zarin & $\mathrm{F}$ \\
\hline 24 & MV-17 & W \\
\hline 25 & Gaspard & W \\
\hline 26 & Gascogne & W \\
\hline 27 & Soisson & W \\
\hline 28 & Shahriar & W \\
\hline 29 & Tous & W \\
\hline 30 & Pishgam & $\mathrm{F}$ \\
\hline 31 & Mihan & W \\
\hline 32 & Oroom & $\mathrm{F}$ \\
\hline 33 & Zaree & W \\
\hline 34 & Inia & $\mathrm{S}$ \\
\hline 35 & Khazar-1 & $\mathrm{S}$ \\
\hline 36 & Mughan-1 & $\mathrm{S}$ \\
\hline 37 & Mughan-2 & $\mathrm{S}$ \\
\hline 38 & Mughan-3 & $\mathrm{S}$ \\
\hline 39 & Golestan & $\mathrm{S}$ \\
\hline 40 & Alborz & $\mathrm{S}$ \\
\hline 41 & Kaveh & $\mathrm{F}$ \\
\hline 42 & Rassoul & $\mathrm{S}$ \\
\hline 43 & Tajan & $\mathrm{S}$ \\
\hline 44 & Shiroudi & $\mathrm{S}$ \\
\hline 45 & Darya & $\mathrm{S}$ \\
\hline 46 & Arta & $\mathrm{S}$ \\
\hline 47 & Morvarid & $S$ \\
\hline 48 & Gonbad & $\mathrm{S}$ \\
\hline 49 & Arvand & $\mathrm{S}$ \\
\hline 50 & Chenab & $\mathrm{S}$ \\
\hline 51 & Bayat & $S$ \\
\hline 52 & Falat & $\mathrm{S}$ \\
\hline 53 & Heirmand & $\mathrm{S}$ \\
\hline 54 & Darab-2 & $\mathrm{S}$ \\
\hline 55 & Atrak & $\mathrm{S}$ \\
\hline 56 & Chamran & $S$ \\
\hline 57 & Star & $\mathrm{S}$ \\
\hline 58 & Dez & $\mathrm{S}$ \\
\hline 59 & Vee/Nac & $\mathrm{S}$ \\
\hline 60 & Line A & $S$ \\
\hline 61 & Aflak & $\mathrm{S}$ \\
\hline
\end{tabular}


Table 1. Continued

\begin{tabular}{|c|c|c|}
\hline No. & Name/Identity & Growth Habit \\
\hline 62 & Baaz & $\mathrm{S}$ \\
\hline 63 & Shahpasand & W \\
\hline 64 & Omid & W \\
\hline 65 & Roshan & $\mathrm{F} / \mathrm{S}$ \\
\hline 66 & Tabassi & $\mathrm{F}$ \\
\hline 67 & Sholleh & S \\
\hline 68 & Sorkhtokhm & S \\
\hline 69 & Adl & $\mathrm{F}$ \\
\hline 70 & Sardari & W \\
\hline 71 & Azar-2 & W \\
\hline 72 & Zagross & $\mathrm{S}$ \\
\hline 73 & Sabalan & W \\
\hline 74 & Sp.Bc of Roshan & $\mathrm{S}$ \\
\hline 75 & Wi. Bc of Roshan & W \\
\hline 76 & Cross of Shahi & W \\
\hline 77 & Maroon & $\mathrm{S}$ \\
\hline 78 & Kavir & S \\
\hline 79 & Hamoon & S \\
\hline 80 & Bam & S \\
\hline 81 & Akbari & S \\
\hline 82 & Sistan & S \\
\hline 83 & Arg & $\mathrm{S}$ \\
\hline 84 & UN-11 & W \\
\hline 85 & Kohdasht & $\mathrm{S}$ \\
\hline 86 & Ohadi & W \\
\hline 87 & Rijav & $\mathrm{F}$ \\
\hline 88 & Rasad & W \\
\hline 89 & Karim & $\mathrm{S}$ \\
\hline 90 & $\mathrm{Ch}$ & W \\
\hline 91 & Homa & W \\
\hline 92 & Norstar & W \\
\hline 93 & Yavarous & $\mathrm{S}$ \\
\hline 94 & Dehdasht & S \\
\hline 95 & Karkheh & S \\
\hline 96 & Aria & S \\
\hline 97 & Dena & S \\
\hline 98 & Behrang & S \\
\hline 99 & Seimareh & S \\
\hline 100 & Saji & $\mathrm{F}$ \\
\hline
\end{tabular}

Numbers of 93-100 are durum wheat.

S, W, and F: Spring, winter and facultative growth type.

volume, respectively.

\section{DNA Extraction and Marker Assay}

Genomic DNA was extracted from $100 \mathrm{mg}$ fresh frozen leaves of individual plants for all genotypes grown in the plastic pot in greenhouse taking a modified CTAB method. ${ }^{35}$ DNA quality was checked by electrophoresis on $0.8 \%$ agarose gel and DNA concentration was determined by a Pico Drop (Pico200). Sixty-six unlinked SSR markers were selected and synthesized according to the information available in the Grain Genes database (http://wheat.pw.usda.gov/GG2). These markers were randomly distributed across the wheat genome. Furthermore, 36 mapped QTLs linked markers from previous studies were selected. Map positions of some of these markers were based on the linkage map published by Somers et al. ${ }^{36}$
Polymerase chain reactions were performed in a Thermal Cycler (Bio-Rad Model thermal cycler) in a volume of $15 \mu \mathrm{L}$ containing: $3 \mu \mathrm{L}$ of DNA template $(50 \mathrm{ng} / \mathrm{mL})$ and $12 \mu \mathrm{L}$ of the master mix containing $7.8 \mu \mathrm{L}$ of $\mathrm{ddH}_{2} \mathrm{O}, 1.5 \mu \mathrm{L}$ of $10 \mathrm{x}$ PCR buffer, $0.3 \mu \mathrm{L}$ of $100 \mathrm{mM} \mathrm{MgCl}_{2}, 0.3 \mu \mathrm{L}$ of $10 \mathrm{mM}$ dNTPs, 0.5 $\mu \mathrm{L}$ of each forward and reverse primers $(1 \mathrm{pmol} / \mathrm{mL})$, and 0.1 $\mu \mathrm{L}$ of Taq polymerase $(500 \mathrm{U} / \mathrm{mL})$. The amplification steps were as follows: 1 cycle at $94^{\circ} \mathrm{C}$ for 4 minutes, then 35 cycles comprising $94^{\circ} \mathrm{C}$ for 1 minute, annealing of primer at $50-60^{\circ} \mathrm{C}$ (depending on the primer) for 1 minute and then extension at $72^{\circ} \mathrm{C}$ for 1 minute. The final extension was carried out at $72^{\circ} \mathrm{C}$ for 10 minutes. The amplification products were electrophoresed on 3.5\% agarose gels (50\% Metaphor and 50\% LE Agarose), and for staining, $3 \mu \mathrm{L}$ Gel Red and dye (1:1 ratio) was added to each sample. Gel scanning was performed using Bio-Rad Gel Doc.

Data Analysis and Association Mapping

Analysis of variance (ANOVA) for quality traits was carried out using ALPHAGEN software version 1.1. ${ }^{37}$ Two sets of SSR markers were used for association analysis. First, 66 SSR primers were used for structure analysis in the 92 bread wheat genotypes. These data were also used for a genomewide approach to identify markers linked to seed quality traits. A second set of these 36 SSR QTLs-linked markers on wheat were tested for targeted association mapping of seed quality traits. For determining the population structure and $\mathrm{K}$ values, genotypic data was processed by the software program STRUCTURE 2.3. ${ }^{38}$ Applying a burn-in of 100000 iterations, followed by 100000 iterations, ${ }^{35} \mathrm{~K}=1-15$ and 5 runs per $\mathrm{K}$ was tested for targeted association mapping of seed quality traits. The fundamental basis of such clustering methods is allocating every individual genotype to $\mathrm{K}$ clusters in such a way that both Hardy-Weinberg equilibrium and linkage equilibrium are valid within clusters, whereas these kinds of equilibrium are missing between clusters. To obtain an association between markers and traits, Q-matrix, quality traits matrix, and scored SSR markers matrix were tested using the mixed linear model (MLM) method of Pritchard et $\mathrm{al},{ }^{38}$ where this method is accomplished in the software package TASSEL 2.1 (http://www.maizegenetics.net/). To obtain the permutationbased test of marker significance and the experiment-wise $P$ values for marker significance, the number of permutations was set at 1000 in this software. Only markers with an allele frequency of $5 \%$ or higher were included in the association mapping analysis.

\section{Results}

Analysis of Variance and Structure Analysis

Analysis of variance showed a significant difference in all quality traits (Table 2). These results indicates that genetic variation exists among genotypes. The Population structure analysis was conducted using genotypic data of 102 SSR markers. To determine the number of subpopulations based on the suggestion of Pritchard and Wen, ${ }^{39}$ we set $\mathrm{K}$ from 1 to 15 . The population structure matrix $(\mathrm{Q})$ was defined by the running structure of $\mathrm{K}=6$ where the highest likelihood 
Table 2. Analysis of Variance for Seed Quality Traits

\begin{tabular}{lccccc}
\hline \multicolumn{1}{c}{} & \multicolumn{3}{c}{ Mean of Square } \\
\hline Source of Variation & $\boldsymbol{d f}$ & Grain Protein & Gluten & Falling Number & SDS Sedimentation \\
\hline Replication & 1 & 4.11 & 744.98 & 275356.10 & 5.44 \\
Block (adj) & 18 & 0.046 & 18.49 & 8281.92 & 2.97 \\
Treatment & 99 & 0.41 & 15.18 & 9898.16 & 39.09 \\
Treatment (adj) & 99 & $0.25^{* *}$ & $7.71^{*}$ & $8407.60^{*}$ & $35.68^{* *}$ \\
Residual & 81 & 0.047 & 4.74 & 6236.85 & 3.01 \\
Total & 199 & & & \\
\hline
\end{tabular}

Note: ${ }^{*}$ and ${ }^{* *}$ significant at 0.05 and 0.01 probability level, respectively.

has been obtained. The standard deviation of this group was lower than other groups (Table 3 ). $\mathrm{K}$ is the number of subpopulations consisted of loci in Hardy-Weinberg and linkage equilibrium. The accessions were subdivided into 6 subpopulations (Figure 1). In Figure 1, the majority of spring growth type genotypes were categorized into 3 subgroups (red, yellow, and aqua). Some of the winter growing genotypes were allocated to 2 subgroups (green and fuchsia) and facultative growing genotypes were classified in blue subgroups. Q-matrix outputs of 6 subpopulations were run $(\mathrm{K}=6)$ for the structure based association analysis.

\section{Marker-Trait Associations}

Association analysis was conducted based on an MLM method. ${ }^{38}$ Association analysis was used for determining the SSR markers associated with the quality-related traits in the structured bread wheat population based on the population structure (Q-matrix). The association with SSR markers for the studied traits is described in table 4 . The results of this study showed that among 36 QTLs derived primers, 29 SSR primers were polymorphic. These primers amplified 58 polymorphic allele markers, ranging from 1 (Xgwm639) to 4 (Xcfd13) with a mean of 2 alleles per locus. Of the total 34 allele markers linked to 4 quality wheat traits, $8,9,6$, and 11 of them were related to grain protein content, gluten, falling number, and SDS sedimentation volume, respectively. Twenty-two of the 258 allele markers from the genome-wide SSR markers were found to exhibit a significant $(P<0.01)$ association with the above-mentioned 4 quality traits along with twelve of the 72 allele markers amplified by QTL-derived SSR primers. Allelic data onto all SSR markers with the significant association is presented in Table 4.

\section{Discussion}

Association mapping can identify QTLs by examining the marker-trait associations which can be attributed to the strength of $\mathrm{LD}$ between markers and functional polymorphisms across a set of diverse germplasm. ${ }^{40}$ Seed quality traits of bread wheat, specifically protein content, gluten, falling number, and SDS sedimentation volume are among the main objectives of a bread wheat breeding program and are effective in grain quality of bread wheat. These traits strongly influence the end use wheat and it's nutritional and market value. Marker-assisted selection (MAS) will

Table 3. Average Logarithm of the Probability of Data Likelihoods (Ln P(D)) of 92 Bread Wheat Genotypes

\begin{tabular}{|c|c|c|c|c|c|c|c|c|}
\hline K & Average Ln P(D) & SD & K & Average Ln $\mathrm{P}(\mathrm{D})$ & SD & K & Average $\ln P(D)$ & SD \\
\hline 1 & -5084.95 & 7.16 & 6 & -4506.95 & 21.26 & 11 & -4845.3 & 23.95 \\
\hline 2 & -4877.4 & 11.55 & 7 & -4554.85 & 25.67 & 12 & -4782.1 & 38.20 \\
\hline 4 & -4685.15 & 17.14 & 9 & -4604.4 & 30.88 & 14 & -4824.4 & 39.63 \\
\hline 5 & -4527.45 & 19.54 & 10 & 4650.9 & 33.12 & 15 & -4901.1 & 41.23 \\
\hline
\end{tabular}

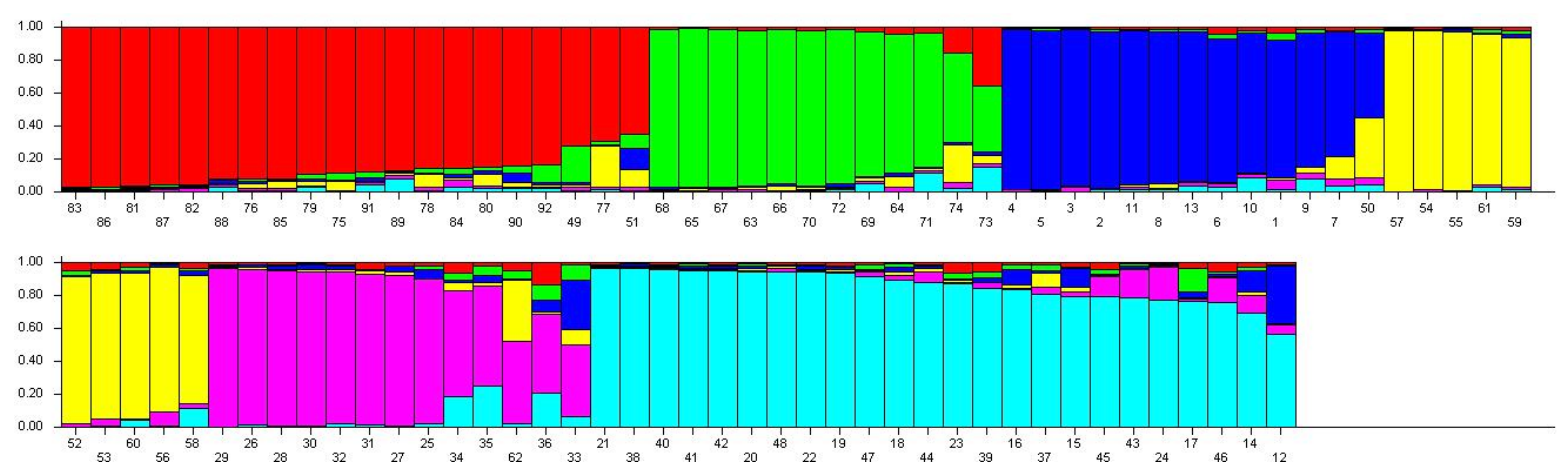

Figure 1. Diagram Derived From the Program Structure 2.3 Showing the Distribution of Bread Wheat Genotypes Into 6 Subpopulations (K=6). 
Table 4. Association of SSR Markers With Traits

\begin{tabular}{|c|c|c|c|c|c|c|}
\hline Trait & & No. & Marker & Chromosome & $P$ Value & Reference \\
\hline \multirow{7}{*}{ Grain protein } & \multirow{4}{*}{$\begin{array}{l}\text { Markers associated with this trait based on the } \\
\text { previous study (QTL-linked markers) }\end{array}$} & 1 & Xcfd13 & $6 \mathrm{~B}, \mathrm{D}$ & $*$ & 6 \\
\hline & & 2 & Xbarc54 & $3 \mathrm{~A}, 6 \mathrm{D}$ & $* *$ & 9 \\
\hline & & 4 & Xbarc320 & $5 \mathrm{D}$ & $* *$ & 41 \\
\hline & & 5 & Xgwm577 & $7 \mathrm{~B}$ & $* *$ & 18 \\
\hline & \multirow{3}{*}{$\begin{array}{l}\text { Related to other traits or used for structure } \\
\text { analysis associated with this trait }\end{array}$} & 1 & Xcfa2141 & $5 \mathrm{~A}, \mathrm{D}$ & $* *$ & \\
\hline & & 2 & Xgwm121 & $5 \mathrm{D}, 7 \mathrm{~B}$ & $*$ & \\
\hline & & 3 & Xgwm515 & $2 \mathrm{~A}, \mathrm{D}$ & $* *$ & \\
\hline \multirow{8}{*}{ Gluten } & \multirow{3}{*}{$\begin{array}{l}\text { Markers associated with this trait (based on the } \\
\text { previous study) }\end{array}$} & 1 & Xcfa2153 & $1 \mathrm{~A}$ & $*$ & 6 \\
\hline & & 2 & Xcfd18 & $5 \mathrm{D}$ & $* *$ & 6 \\
\hline & & 3 & Xbarc200 & $2 \mathrm{~B}$ & $*$ & 6 \\
\hline & \multirow{5}{*}{$\begin{array}{l}\text { Related to other traits or used for structure } \\
\text { analysis associated with this trait }\end{array}$} & 1 & Xbarc74 & $5 \mathrm{~B}$ & $* *$ & \\
\hline & & 3 & Xgwm88 & $6 \mathrm{~B}$ & $* *$ & \\
\hline & & 4 & Xgwm135 & $1 \mathrm{~A}$ & $* *$ & \\
\hline & & 5 & Xgwm539 & $2 \mathrm{D}$ & $*$ & \\
\hline & & 6 & Xgwm577 & $7 \mathrm{~B}$ & $* *$ & \\
\hline \multirow{6}{*}{ Falling number } & \multirow{2}{*}{$\begin{array}{l}\text { Markers associated with this trait (based on the } \\
\text { previous study) }\end{array}$} & 1 & Xbarc80 & 1B & $*$ & 10 \\
\hline & & 2 & Xgwm113 & $4 \mathrm{D}$ & $*$ & 10 \\
\hline & \multirow{4}{*}{$\begin{array}{l}\text { Related to other traits or used for structure } \\
\text { analysis associated with this trait }\end{array}$} & 1 & Xcfd40 & $5 \mathrm{~A}, \mathrm{D}$ & $*$ & \\
\hline & & 2 & Xbarc168 & $2 \mathrm{D}$ & $* *$ & \\
\hline & & 3 & Xgwm295 & 7D & $* *$ & \\
\hline & & 4 & Xgwm639 & $5 \mathrm{~A}, \mathrm{~B}, \mathrm{D}$ & $* *$ & \\
\hline \multirow{9}{*}{$\begin{array}{l}\text { SDS sedimentation } \\
\text { volume }\end{array}$} & \multirow{2}{*}{$\begin{array}{l}\text { Markers associated with this trait (based on the } \\
\text { previous study) }\end{array}$} & 1 & Xgwm371 & $5 B, D$ & $*$ & 42 \\
\hline & & 2 & Xwmc453 & $2 A, B, D$ & $*$ & 9 \\
\hline & \multirow{7}{*}{$\begin{array}{l}\text { Related to other traits or used for structure } \\
\text { analysis associated with this trait }\end{array}$} & 1 & Xbarc86 & $3 \mathrm{~A}$ & $* *$ & \\
\hline & & 4 & Xgwm33 & $1 \mathrm{~A}, \mathrm{~B}, \mathrm{D}$ & $* *$ & \\
\hline & & 5 & Xgwm88 & $6 \mathrm{~B}$ & $* *$ & \\
\hline & & 6 & Xgwm131 & $1,3,7 \mathrm{~B}$ & $*$ & \\
\hline & & 7 & Xgwm369 & $3 \mathrm{~A}, 4 \mathrm{~B}$ & $*$ & \\
\hline & & 8 & Xwmc317 & $2 \mathrm{BL}$ & $* *$ & \\
\hline & & 9 & Xwmc596 & $7 \mathrm{~A}$ & $* *$ & \\
\hline
\end{tabular}

** and * significant at $5 \%$ and $1 \%$ levels of probability, respectively.

enhance the efficiency of the breeding process. Moreover, the accomplishment of MAS allows the selection of individuals carrying the suitable alleles at the target loci. The markertrait associations revealed for all 4 traits QTL distributed throughout the genome.

In previous studies, 18 markers that linked with protein content were used. In this study, we identified only 5 markers including Xcfd13 marker on chromosomes $6 \mathrm{~B}$ and $6 \mathrm{D}$, Xbarc54 on chromosomes $3 \mathrm{~A}$ and $6 \mathrm{D}, \mathrm{Xbarc} 86$ on chromosome $3 \mathrm{~A}, \mathrm{Xbarc} 320$ on chromosome $5 \mathrm{D}$, and finally Xgwm577 on chromosome 7B which were shown to be associated (Table 4). This result confirmed the QTL locations that were identified in some previous studies., ${ }^{9,18,41}$ Tadesse et al reported that 2 DArT markers on $5 \mathrm{~B}$ were highly associated with protein content and alveograph strength. ${ }^{19}$ In microsatellite consensus map, some of these SSR markers have been mapped as Xgwm577 in the distance $137 \mathrm{cM}$ on the short arm of $7 \mathrm{~B}, \mathrm{Xcfd} 13$ in the distance $17 \mathrm{cM}$ on the short arm $6 \mathrm{~B}$ and $21 \mathrm{cM}$ on the long arm of $6 \mathrm{D}$, and $\mathrm{Xbarc} 54$ on the distance $47 \mathrm{cM}$ on the short arm 6D. ${ }^{36}$

Additionally, Xcfa2141 on chromosome 5A, 5D, Xgwm121 and Xgwm515 on chromosome 5D, 7B, 2A, and 2D, were linked to grain protein content. These markers were used for population structure. It is possible which indicate a systematic type I error and false positive. ${ }^{43}$ Jochen et al, using the association mapping in winter wheat cultivars, studied QTLs linked to the protein quality-related traits and detected 4 QTLs associated with this trait located on the chromosomes $3 \mathrm{~A}, 1 \mathrm{~B}$, $5 \mathrm{D}$, and 2D. ${ }^{28}$ Furthermore, an experiment was carried out in different environmental conditions and identified QTLs placed on the chromosome 7A. ${ }^{44}$ Using recombinant inbred lines, Blanco et al identified 3 QTLs on chromosomes 6AS, $2 \mathrm{AS}$, and $7 \mathrm{BL}$ that controlled this trait. ${ }^{45}$ Joppa et al reported that $66 \%$ of the variation of QTLs that control protein content was related to chromosome $6 \mathrm{~B} .{ }^{46}$ These loci located on the short arm of chromosome $6 \mathrm{~B}$ near the centromere. As well 
as Joppa et al, Chee et al reported that QTLs for the protein quality were on the short arm of chromosome $6 \mathrm{~B} .{ }^{46,47}$ It can be concluded that chromosome $6 \mathrm{~B}$ has an important role in the genetic control of this trait.

Glutenin and gliadins are important quality traits in wheat. Nine QTLs were identified for gluten on chromosomes $5 \mathrm{D}$, $2 \mathrm{~B}, 5 \mathrm{~A}, 7 \mathrm{~B}, 2 \mathrm{D}, 5 \mathrm{~B}, 1 \mathrm{~A}$, and $6 \mathrm{~B}$. In a previous study, Xcfd18, $\mathrm{Xbarc200}$, and Xcfa2153 markers were known as associated QTLs with this trait located on chromosomes 5D, 2B and $1 \mathrm{~A}$, respectively. ${ }^{6}$ The results of the present study accorded to the results of Zhang et al study. ${ }^{6}$ Somers et al mapped Xbarc200 marker at a distance of $37 \mathrm{cM}$ on the short arm of chromosome $2 \mathrm{~B} .{ }^{36} \mathrm{In}$ another study, it was found that the amounts of gluten are controlled by 2 QTLs that located on chromosomes 5B and 7A..$^{48}$ The genetic control of glutenin and gliadin is relatively well known in wheat. ${ }^{28,49}$ It can be concluded that association mapping can complement previous QTL information and provide opportunities for further wheat improvement programs.

Late maturity $a$-amylase is a genetic defect in wheat which results in the production of $a$-amylase, shown as substandard falling numbers, in the absence of pre-harvest rain and under cool temperatures during ripening. ${ }^{12}$ Wheat seeds with high $a$-amylase activity have little economic value because their handling and storage are difficult. ${ }^{50,51}$ Previous investigations had identified 5 SSR markers with a significant association with falling number. In the present study, these markers were tested for targeted association mapping. The result of the present study indicated that Xgwm80 and Xbarc113 markers as QTLs on chromosomes $1 \mathrm{~B}$ and $4 \mathrm{D}$ were significantly associated with this trait (Table 4). This result was also confirmed by another researcher finding. ${ }^{10}$ In the Somers wheat consensus map, Xbarc80 marker was located on long arm of chromosome $1 \mathrm{~B}$ at a distance of $106 \mathrm{cM}^{36}$ The present study confirmed a significant correlation between falling number and the markers located on chromosome 6B. Through using association mapping to identify the exact location of $a$-amylase genes in hexaploid wheat, a significant correlation between these traits and markers located on chromosome 7B was observed. ${ }^{12}$

Furthermore, 4 SSR markers used for population structure assay displayed to be associated with falling number and located on chromosomes 5A, 5B, 5D, 7D, and 2D. These results showed that possibly this association may be false positives. Although, false positives can also arise from situations where the statistical test is valid and the association exists, but there is an association with population structure instead of the trait of interest..$^{52}$ This matter is recommended to be examined in future studies.

Five SSR markers that in the previous studies were shown to be linked to SDS sedimentation were selected for association analysis. Among them, Xwmc $453^{9}$ and Xgwm $371^{42}$ markers were found to exhibit a significant association with SDS sedimentation. These markers were located on the chromosomes 2A, 2B, 2D, 5B, and 5D. Xwmc453 marker was mapped on the short arm of chromosome $2 \mathrm{D}$ at a distance of $43 \mathrm{cM}^{36}$ Furthermore, Xbarc86 marker was associated with SDS sedimentation and protein content. This marker has a pleiotropic effect. Nine SSR markers used for other quality traits or population structure analysis were associated significantly with SDS sedimentation. Using QTL mapping, Blanco et al also found QTLs that located on chromosome $3 \mathrm{AS}, 3 \mathrm{BL}, 5 \mathrm{AL}, 6 \mathrm{AL}$, and 7BS linked with this trait. ${ }^{40} \mathrm{Huang}$ et al reported 3 QTLs on 1B, 2D, and 5D chromosomes. ${ }^{9}$ In another study using association mapping analysis in bread wheat, QTLs on chromosome 2D, 3A, 5D, and $1 \mathrm{~A}$ were identified for SDS sedimentation. ${ }^{28}$ These results are in agreement with the results of the present study. Results of this study and previous investigation confirmed that $2 \mathrm{D}$ and $5 \mathrm{D}$ chromosomes had a more significant role in controlling this trait.

\section{Conclusions}

In the present study, we conclude that association mapping in bread wheat is not only suitable but can also reveal additional QTLs not found in bi-parental populations, because the genetic variation within an association mapping panel is usually much greater than that in a conventional linkage mapping populations.

\section{Authors' Contributions}

RMD and GN have made contributions towards the design, execution, and field and laboratory data collection. MRB and AE have helped to data analysis.

\section{Conflict of Interest Disclosures}

The authors declare they have no conflicts of interest.

\section{Acknowledgments}

Authors thank Elham and Aram salahvarzi, Ziba Fuladvand, and Abbas Rezaeizad for technical assistance.

\section{References}

1. Sorrells ME, Yu J. Linkage Disequilibrium and Association Mapping in the Triticeae. In: Muehlbauer GJ, Feuillet C, eds. Genetics and Genomics of the Triticeae. New York, NY: Springer US; 2009:655683.

2. Oraguzie NC, Wilcox PL. An overview of association mapping. In: Oraguzie NC, Rikkerink EHA, Gardiner SE, De Silva HN, eds. Association Mapping in Plants. New York: Springer-Verlag; 2007:1-10.

3. Benjamin S, Melchinger AE. An introduction to association mapping in plants. CAB Reviews: Perspectives in Agriculture, Veterinary Science, Nutrition and Natural Resources. 2010;5 (039):1-9. doi:10.1079/PAVSNNR20105039.

4. Cardon LR, Bell JI. Association study designs for complex diseases. Nat Rev Genet. 2001;2(2):91-99. doi:10.1038/35052543.

5. Jannink J, Bink MC, Jansen RC. Using complex plant pedigrees to map valuable genes. Trends Plant Sci. 2001;6(8):337-342. doi:10.1016/S1360-1385(01)02017-9.

6. Zhang Y, Tang J, Zhang Y, et al. QTL mapping for quantities of protein fractions in bread wheat (Triticum aestivum L.). Theor Appl Genet. 2011;122(5):971-987. doi:10.1007/s00122-010-1503-6.

7. Campbell KG, Bergman CJ, Gualberto DG, et al. Quantitative trait loci associated with kernel traits in a soft $\times$ hard wheat cross. Crop Sci. 1999;39(4):1184-1195. doi:10.2135/cropsci1999.0011183X 003900040039x.

8. Galande AA, Tiwari R, Ammiraju JSS, et al. Genetic analysis of 
kernel hardness in bread wheat using PCR-based markers. Theor Appl Genet. 2001;103(4):601-606. doi:10.1007/pl00002915.

9. Huang XQ, Cloutier S, Lycar L, et al. Molecular detection of QTLS for agronomic and quality traits in a doubled haploid population derived from two Canadian wheats (Triticum aestivum L.). Theor Appl Genet. 2006;113(4):753-766. doi:10.1007/s00122-0060346-7.

10. Kunert A, Naz AA, Dedeck O, Pillen K, Leon J. AB-QTL analysis in winter wheat: I. Synthetic hexaploid wheat (T. turgidum ssp. dicoccoides $\times$ T. tauschii) as a source of favourable alleles for milling and baking quality traits. Theor Appl Genet. 2007;115(5):683-695. doi:10.1007/s00122-007-0600-7.

11. Sun X, Marza F, Ma H, Carver BF, Bai G. Mapping quantitative trait loci for quality factors in an inter-class cross of US and Chinese wheat. Theor Appl Genet. 2010;120(5):1041-1051. doi:10.1007/ s00122-009-1232-x.

12. Emebiri LC, Oliver JR, Mrva K, Mares D. Association mapping of late maturity $\alpha$-amylase (LMA) activity in a collection of synthetic hexaploid wheat. Mol Breed. 2010;26(1):39-49. doi:10.1007/ s11032-009-9375-7.

13. Prasad M, Kumar N, Kulwal PL, et al. QTL analysis for grain protein content using SSR markers and validation studies using NILs in bread wheat. Theor Appl Genet. 2003;106(4):659-667. doi:10.1007/s00122-002-1114-y.

14. Groos C, Robert N, Bervas E, Charmet G. Genetic analysis of grain protein-content, grain yield and thousand-kernel weight in bread wheat. Theor Appl Genet. 2003;106(6):1032-1040. doi:10.1007/ s00122-002-1111-1.

15. Breseghello F, Finney PL, Gaines $C$, et al. Genetic loci related to kernel quality differences between a soft and a hard wheat cultivar. Crop Sci. 2005;45(5):1685-1695. doi:10.2135/cropsci2004.0310.

16. Kuchel $H$, Langridge $P$, Mosionek L, Williams K, Jefferies SP. The genetic control of milling yield, dough rheology and baking quality of wheat. Theor Appl Genet. 2006;112(8):1487-1495. doi:10.1007/s00122-006-0252-z.

17. Tsilo TJ, Hareland GA, Simsek S, Chao S, Anderson JA. Genome mapping of kernel characteristics in hard red spring wheat breeding lines. Theor Appl Genet. 2010;121(4):717-730. doi:10.1007/ s00122-010-1343-4

18. Blanco A, Mangini G, Giancaspro A, et al. Relationships between grain protein content and grain yield components through quantitative trait locus analyses in a recombinant inbred line population derived from two elite durum wheat cultivars. Mol Breed. 2012;30(1):79-92. doi:10.1007/s11032-011-9600-z.

19. Tadesse W, Ogbonnaya FC, Jighly A, et al. Genome-wide association mapping of yield and grain quality traits in winter wheat genotypes. PLoS One. 2015;10(10):e0141339. doi:10.1371/ journal.pone.0141339.

20. Blanco A, Bellomo MP, Lotti C, et al. Genetic mapping of sedimentation volume across environments using recombinant inbred lines of durum wheat. Plant Breed. 1998;117(5):413-417. doi:10.1111/j.1439-0523.1998.tb01965.x.

21. Rousset M, Brabant P, Kota RS, Dubcovsky J, Dvorak J. Use of recombinant substitution lines for gene mapping and QTL analysis of bread making quality in wheat. Euphytica. 2001;119(1):81-87. doi:10.1023/a:1017530002612.

22. Li Y, Song Y, Zhou R, Branlard G, Jia J. Detection of QTLs for bread-making quality in wheat using a recombinant inbred line population. Plant Breed. 2009;128(3):235-243. doi:10.1111/ j.1439-0523.2008.01578.x.

23. Zanke CD, Ling J, Plieske J, et al. Analysis of main effect QTL for thousand grain weight in European winter wheat (Triticum aestivum L.) by genome-wide association mapping. Front Plant Sci. 2015;6:644. doi:10.3389/fpls.2015.00644

24. Zondervan KT, Cardon LR. The complex interplay among factors that influence allelic association. Nat Rev Genet. 2004;5(2):89100. doi:10.1038/nrg1270.

25. Yu J, Zhang Z, Zhu C, et al. Simulation appraisal of the adequacy of number of background markers for relationship estimation in association mapping. Plant Genome. 2009;2(1):63-77. doi:10.3835/plantgenome2008.09.0009.

26. Breseghello F, Sorrells ME. Association mapping of kernel size and milling quality in wheat (Triticum aestivum L.) cultivars. Genetics. 2006;172(2):1165-1177. doi:10.1534/genetics.105.044586.

27. Neumann K, Kobiljski B, Dencic S, Varshney RK, Börner A. Genome-wide association mapping: a case study in bread wheat (Triticum aestivum L.). Mol Breed. 2011;27(1):37-58. doi:10.1007/ s11032-010-9411-7.

28. ReifJC, Gowda M, Maurer HP, et al. Association mapping for quality traits in soft winter wheat. Theor Appl Genet. 2011;122(5):961970. doi:10.1007/s00122-010-1502-7.

29. Abdollahi Mandoulakani B, Nasri S, Dashchi S, Arzhang S, Bernousi I, Abbasi Holasou H. Preliminary evidence for associations between molecular markers and quantitative traits in a set of bread wheat (Triticum aestivum L.) cultivars and breeding lines. C R Biol. 2017;340(6-7):307-313. doi:10.1016/j.crvi.2017.05.001.

30. Shahzad M, Khan SH, Khan AS, Sajjad M, Rehman A, Khan AI. Identification of QTLs on chromosome 1B for grain quality traits in bread wheat (Triticum aestivum L.). Cytol Genet. 2016;50(2):8995. doi:10.3103/s0095452716020110.

31. Kumari S, Jaiswal V, Mishra VK, Paliwal R, Balyan HS, Gupta PK. QTL mapping for some grain traits in bread wheat (Triticum aestivum L.). Physiol Mol Biol Plants. 2018;24(5):909-920. doi:10.1007/s12298-018-0552-1.

32. Krystkowiak K, Langner M, Adamski T, et al. Interactions between Glu-1 and Glu-3 loci and associations of selected molecular markers with quality traits in winter wheat (Triticum aestivum L.) DH lines. J Appl Genet. 2017;58(1):37-48. doi:10.1007/s13353016-0362-5.

33. Kaur P, Vyas $P$, Sharma P, Sheikh I, Kumar R, Dhaliwal HS. Marker-Assisted Breeding of Recombinant 1RS.1BL Chromosome for Improvement of Bread Making Quality and Yield of Wheat (Triticum aestivum L.). In: Mukhopadhyay K, Sachan A, Kumar M, eds. Applications of Biotechnology for Sustainable Development. Singapore: Springer; 2017:181-190. doi:10.1007/978-981-105538-6_21.

34. American Association of Cereal Chemists (AACC). Approved Method of the AACC. 10th ed. St. Paul: AACC; 2000.

35. Doyle JJ. Isolation of plant DNA from fresh tissue. Focus. 1990;12:13-15.

36. Somers DJ, Isaac P, Edwards K. A high-density microsatellite consensus map for bread wheat (Triticum aestivum L.). Theor Appl Genet. 2004;109(6):1105-1114. doi:10.1007/s00122-004-17407.

37. ALPHANAL. A program for analysis of alpha lattice incomplete block experiments version 1.1. Edinburg: AFRC unit of statistics; 1986.

38. Pritchard JK, Wen X, Falush D. Documentation for structure Software, version 2.3. Chicago: Department of Human Genetics University of Chicago; 2010.

39. Pritchard JK, Wen X. Documentation for structure Software, version 2.3. Chicago: Department of Human Genetics University of Chicago; 2007.

40. Zhu C, Gore M, Buckler ES, Yu J. Status and Prospects of Association Mapping in Plants. Plant Genome. 2008;1(1):5-20. doi:10.3835/ plantgenome2008.02.0089.

41. Zhao L, Zhang KP, Liu B, Deng ZY, Qu HL, Tian JC. A comparison of grain protein content QTLs and flour protein content QTLs across environments in cultivated wheat. Euphytica. 2010;174(3):325335. doi:10.1007/s10681-009-0109-z.

42. Kerfal S, Giraldo P, Rodriguez-Quijano $M$, et al. Mapping quantitative trait loci (QTLs) associated with dough quality in a soft×hard bread wheat progeny. J Cereal Sci. 2010;52(1):46-52. doi:10.1016/j.jcs.2010.03.001.

43. Rezaeizad A, Wittkop B, Snowdon R, et al. Identification of QTLs for phenolic compounds in oilseed rape (Brassica napus 
L.) by association mapping using SSR markers. Euphytica. 2011;177(3):335-342. doi:10.1007/s10681-010-0231-y.

44. Blanco A, Pasqualone A, Troccoli A, Di Fonzo N, Simeone R. Detection of grain protein content QTLs across environments in tetraploid wheats. Plant Mol Biol. 2002;48(5-6):615-623. doi:10.1023/a:1014864230933.

45. Blanco A, Simeone R, Gadaleta A. Detection of QTLs for grain protein content in durum wheat. Theor Appl Genet. 2006;112(7):1195-1204. doi:10.1007/s00122-006-0221-6.

46. Joppa LR, Du C, Hart GE, Hareland GA. Mapping gene (s) for grain protein in tetraploid wheat (Triticum turgidum L.) using a population of recombinant inbred chromosome lines. Crop Sci. 1997;37(5):1586-1589. doi:10.2135/cropsci1997.0011183X0037 00050030x.

47. Chee PW. Introgression of a high protein gene from LDN (DIC6B) substitution line. In A. E. Slinkard AE, ed. International Wheat Genetics Symposium. 9th ed. Vol 2. Saskatoon: University of Saskatchewan; 1998:179-181.

48. Pshenichnikova TA, Ermakova MF, Chistyakova AK, et al.
Mapping of the quantitative trait loci (QTL) associated with grain quality characteristics of the bread wheat grown under different environmental conditions. Russ J Genet. 2008;44(1):74-84. doi:10.1134/s1022795408010109.

49. Varshney RK, Tuberosa R. Genomics-Assisted Crop Improvement -- Volume 2: Genomics Applications in Crops. Springer; 2007:2550. doi:10.1007/978-1-4020-6297-1.

50. Derera NF. The effects of preharvest rain. In: Derera NF, ed. Preharvest Field Sprouting in Cereals. Boca Raton, USA: CRS Press Inc; 1989:1-14.

51. Edwards RA, Ross AS, Mares DJ, Ellison FW, Tomlinson JD. Enzymes from rain-damaged and laboratory-germinated wheat I. Effects on product quality. J Cereal Sci. 1989;10(2):157-167. doi:10.1016/S0733-5210(89)80044-X.

52. Ersoz ES, Yu J, Buckler ES. Applications of linkage disequilibrium and association mapping in maize. In: Kriz AL, Larkins BA, eds. Molecular genetic approaches to maize improvement, biotechnology in agriculture and forestry. Berlin: Springer; 2009:173-195. 